University of Nebraska - Lincoln

DigitalCommons@University of Nebraska - Lincoln

\title{
Monitoring runoff from cattle-grazed pastures for a phosphorus loss quantification tool
}

\author{
Peter A. Vadas \\ USDA-ARS, U.S. Dairy Forage Research Center, peter.vadas@ars.usda.gov \\ Dennis L. Busch \\ University of Wisconsin-Platteville \\ J. Mark Powell \\ USDA-ARS, mark.powell@wisc.edu \\ Geoff E. Brink \\ USDA-ARS, U.S. Dairy Forage Research Center, Geoffrey.Brink@ars.usda.gov
}

Follow this and additional works at: https://digitalcommons.unl.edu/usdaarsfacpub

Vadas, Peter A.; Busch, Dennis L.; Powell, J. Mark; and Brink, Geoff E., "Monitoring runoff from cattlegrazed pastures for a phosphorus loss quantification tool" (2014). Publications from USDA-ARS / UNL Faculty. 1475.

https://digitalcommons.unl.edu/usdaarsfacpub/1475

This Article is brought to you for free and open access by the U.S. Department of Agriculture: Agricultural Research Service, Lincoln, Nebraska at DigitalCommons@University of Nebraska - Lincoln. It has been accepted for inclusion in Publications from USDA-ARS / UNL Faculty by an authorized administrator of DigitalCommons@University of Nebraska - Lincoln. 


\title{
Monitoring runoff from cattle-grazed pastures for a phosphorus loss quantification tool
}

\author{
Peter A. Vadas ${ }^{a, *}$, Dennis L. Busch ${ }^{b}$, J.Mark Powell ${ }^{a}$, Geoff E. Brink ${ }^{a}$ \\ a USDA-ARS, U.S. Dairy Forage Research Center, 1925 Linden Drive West, Madison, WI 53706, United States \\ ${ }^{\mathrm{b}}$ University of WI-Platteville School of Agriculture, United States
}

\section{A R T I C L E I N F O}

\section{Article history:}

Received 7 March 2014

Received in revised form 26 August 2014

Accepted 28 August 2014

Available online $\mathrm{xxx}$

\section{Keywords:}

Phosphorus

Runoff

Grazing

Model

\begin{abstract}
A B S T R A C T
Nitrogen (N) and phosphorus (P) loss from agriculture persists as a water quality impairment issue. For dairy farms, nutrients can be lost from cropland, pastures, barnyards, and outdoor cattle lots. We monitored $\mathrm{N}$ and $\mathrm{P}$ loss in runoff from dairy and beef grazed pastures for two years in southwest Wisconsin, USA and tested the accuracy of the Annual P Loss Estimator (APLE) model to predict runoff P from pastures using study and literature data. About 3-10\% of annual precipitation became runoff from the pastures, and sediment loss was very low due to well-established vegetation. Measured annual nutrient loss in runoff was also low, averaging $1.0 \mathrm{~kg} \mathrm{ha}^{-1}$ for total $\mathrm{P}$ and $2.9 \mathrm{~kg} \mathrm{ha}^{-1}$ for total $\mathrm{N}$. Runoff sediment and particulate $\mathrm{N}$ and $\mathrm{P}$ concentrations were well related to each other and tended to be greater in rainfall-induced runoff than snowmelt runoff. Conversely, dissolved $\mathrm{N}$ and $\mathrm{P}$ runoff concentrations were greater in snowmelt runoff. APLE was able to reliably predict annual P loss in runoff, estimating that the average relative contribution to total pasture P loss was about $10 \%$ from fertilizer, $15 \%$ from soil dissolved P, 30\% from dung, and 45\% from soil erosion. Our study has increased the ability to develop reliable models for estimating the impact of cattle grazing pastures on nutrient runoff, which will be valuable in estimating whole-farm $P$ loss from dairy production systems and identifying areas on dairy farms where P loss remediation should be targeted.
\end{abstract}

Published by Elsevier B.V.

\section{Introduction}

Non-point source pollution of surface waters by nitrogen $(\mathrm{N})$ and phosphorus $(\mathrm{P})$ can accelerate eutrophication and limit water use for drinking, recreation, and industry (Parris, 2011). Because $\mathrm{N}$ and $\mathrm{P}$ loss from agricultural systems via surface runoff has consistently been identified as a non-point pollution source (Bennett et al., 2001), there is a need to quickly and accurately quantify runoff nutrient loss from farms, identify the major sources of farm loss, and develop management practices to reduce that loss. For cattle farms, possible sources of runoff $\mathrm{N}$ and $\mathrm{P}$ loss include cropland, grazed pastures, and outside cattle holding areas, such as feedlots, barnyards, exercise lots, or over-wintering lots. On such farms, it is necessary to estimate nutrient loss in runoff from all of these sources to effectively target remediation practices (McDowell and Nash, 2012).

There has been significant research conducted to monitor $\mathrm{N}$ and $\mathrm{P}$ loss in runoff from grazed pastures (Edwards et al., 2000; Halliwell et al., 2000; Nash et al., 2000; O'reagain et al., 2005; Haan et al., 2006;

\footnotetext{
* Corresponding author. Tel.: +1 608890 0069; fax: +1 6088900076

E-mail address: peter.vadas@ars.usda.gov (P.A. Vadas).
}

Owens and Shipitalo, 2006; Capece et al., 2007; McDowell et al., 2007; Dougherty et al., 2008). However, considerably less pasture runoff research has been conducted compared to nutrient loss from cultivated cropland, and most of it has been conducted in Australia, New Zealand, and the United Kingdom. In the U.S., only limited field-scale, natural precipitation, pasture runoff research have been conducted where the major source of nutrient addition is through grazing animals (Olness et al., 1975; Menzel et al., 1978; Chichester et al., 1979; Schepers and Francis, 1982; Owens and Shipitalo, 2006; Capece et al., 2007). The reason for this is unclear. It may be that relative to row crops, pastures constitute much fewer acres on cattle farms in areas where water quality impairment is a problem and are not seen as a major contributor to waterbody eutrophication, especially since pastures typically have less nutrient inputs and soil erosion than row crops. However, as the demand for improved water quality increases, the use of pastures and the associated decrease in nutrient loss through soil erosion may become a more attractive land use on cattle farms (Rotz et al., 2009). There is thus a need to document the potential water quality impact of cattle pastures and have tools to estimate this impact relative to other land uses on cattle farms.

As quantifying runoff nutrient loss from all sources on a cattle farm through physical monitoring is expensive and lengthy, 
simulation models can be a more rapid, cost effective ways to estimate $\mathrm{N}$ and P loss (Radcliffe et al., 2009). For P, quantitative agricultural loss models can generally be grouped into two categories. The first group is highly parameterized, daily time-step, process-based models like the farm-scale Integrated Farm Systems Model (IFSM) (Sedorovich et al., 2007), or field to watershed-scale models like the Soil and Water Assessment Tool (SWAT) (Arnold et al., 1998) or the Agricultural Policy/Environmental eXtender (APEX) (Gassman et al., 2010). The second group is more user-friendly, seasonal to annual time-step models, such as the Annual P Loss Estimator (APLE) (Vadas et al., 2009, 2012) and the Wisconsin P Index (WI PI) (Good et al., 2012), that are a combination of process-based and empirical $P$ loss equations. However, all of these tools have shortcomings when simulating $P$ loss via surface runoff from cattle-grazed pastures. The WI PI and APLE have been developed to estimate P loss from agricultural cropland, but have not been tested for grazed pastures; IFSM apparently does not simulate P loss from dung deposited during grazing; and currently available versions of SWAT and APEX do not simulate manure or dung on the soil surface, which precludes adequate simulation of $\mathrm{P}$ loss from dung in pastures. Therefore, these tools should be updated to better simulate P loss from dairy farms in general and cattle-grazed pastures in particular. Vadas et al. (2011) recently developed a daily time step model for P loss from grazing cattle pastures that could be integrated into models like IFSM, SWAT, and APEX. Similar updates are needed for annual models like APLE and the WI PI.

The objectives of our project were to: (i) monitor $\mathrm{N}$ and $\mathrm{P}$ loss in runoff from beef and dairy-grazed pastures in southwest Wisconsin, USA, and (ii) use the runoff data, as well as data from published scientific literature, to test the ability of APLE to predict $P$ loss in runoff from cattle-grazed pastures. The long-term goal of this research is to develop modeling tools that can estimate whole-farm P loss from dairy farms and appropriately target farm areas for P loss remediation. Assessing the pasture component of dairy farms is one step in that process.

\section{Methods and materials}

\subsection{Pasture runoff monitoring}

We established eight, hydrologically isolated basins ranging in size from 0.3 to 0.4 ha in an existing cattle pasture at the University of Wisconsin-Platteville Pioneer Farm $\left(42.71^{\circ} \mathrm{N}\right.$, $90.39^{\circ} \mathrm{W}$ ) (Fig. 1). The Pioneer Farm is a 174 ha production

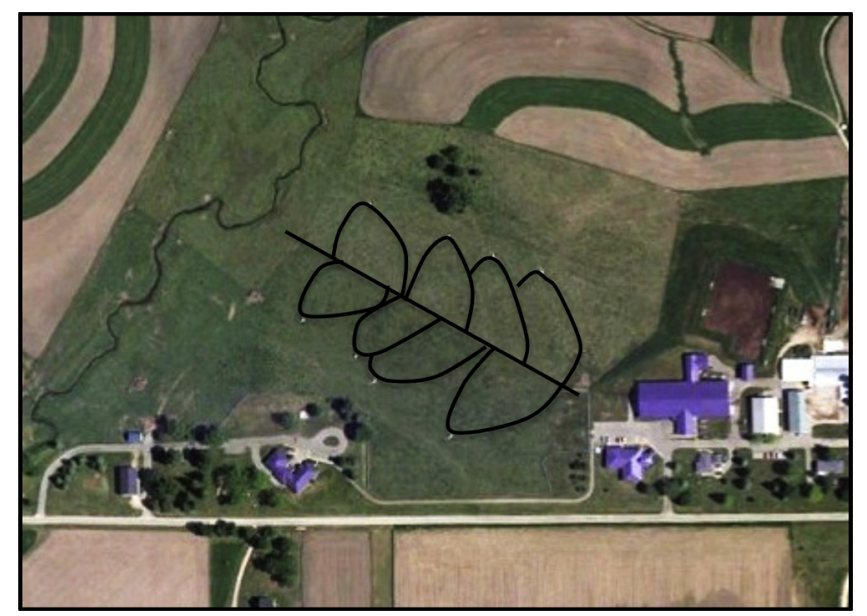

Fig. 1. Aerial view of the field showing the location of the eight runoff basins within an existing cattle pasture. farm located in the unglaciated area of southwest Wisconsin in the Northern Mississippi Valley Loess Hills. The dominant soil is a moderately eroded Tama soil series (fine-silty, mixed, superactive, mesic Typic Argiudoll), with B and C slope classes. The runoff basins were oriented so that four were on a south-facing slope (5-8\%) and four were on a north-facing slope (5-8\%), with a ridge separating the two groups. The eight basins were within existing pastures grazed by beef and non-lactating dairy cattle, and were separated from each other either by the ridge at the upslope edge or by earthen berms. The southern four basins were within a 7.3 ha pasture grazed by beef cattle, and the northern four basins were within a 6.1 ha pasture grazed by non-lactating dairy cattle. Thus, the eight basins all received generally the same management. Cattle were given free access to the pastures starting in mid-May until mid-November, with daily numbers of dairy cattle ranging from 14 to 34 and beef cattle from 18 to 28 . Annual stocking rates were approximately 2.7 animal units ha ${ }^{-1}$, with one animal unit defined as a mature cow at about $450 \mathrm{~kg}$. Excess pasture growth was cut for hay and baled, typically in mid-July. This management for non-lactating cattle is typical for this region, with cattle generally given access to pastures for grazing from early to mid spring until late fall, with supplemental feeding as needed. Outside of this period, cattle are housed off of pastures, typically in small, dedicated lots known as over-wintering areas.

We installed runoff collection systems at the outlet of each basin. Each system consisted of wooden wing walls that channeled surface runoff into an $\mathrm{H}$-flume. Ultrasonic sensors (Automated Products Group IRU-5000) measured and logged (Campbell Scientific CR206) water stage in the flumes in one-minute intervals to estimate runoff volumes. Flow-paced composite runoff samples were collected from flumes using an automated sampler (ISCO 3700), with sampling frequency adjusted remotely for each event to ensure collection of representative samples for an entire event, such that samples were collected more frequently as flow increased. Samples were pumped into 1-L containers and collected within $24 \mathrm{~h}$ of the end of the runoff event. A discharge-weighted sample was then produced for each runoff event by calculating the percentage of the total runoff-event volume that each discrete sample represented, collecting appropriate aliquots from each discrete sample by using a churn splitter, and combining aliquots into one composite sample. Flow-compositing monitoring is a common procedure that reliably estimates pollutant loads for runoff events (Harmel and King, 2005).

The sampling system was inside a covered shelter and was equipped with radiant heaters to allow runoff collection year round. We measured daily rainfall with existing equipment at the Pioneer Farm, and obtained snowfall data from a weather station located $\sim 35 \mathrm{~km}$ to the southwest of the field site. In this region, there is predominately frozen precipitation from December through March. Runoff from snowmelt and rain-on-snow events is typical throughout February and March and can account for a majority of total annual runoff. Outside of this snowmelt period, runoff does occur, but is typically less and occurs inconsistently, often as a result of large storms.

The runoff sampling protocol described above generated a single, composite runoff sample for each event for each runoff basin. We analyzed all composite runoff samples for sediment, N, and $P$ at the USDA-ARS Dairy Forage Research Center in Madison, WI. We measured total sediment gravimetrically by drying a known quantity $(\sim 50 \mathrm{~mL})$ of a well-shaken runoff sample at $60^{\circ} \mathrm{C}$ until all water had evaporated. We then determined the weight of the remaining sediment and determined sediment content $\left(\mathrm{g} \mathrm{L}^{-1}\right)$ as the mass of that sediment in the original volume of sample. We filtered runoff samples through $0.45 \mu \mathrm{m}$ filters, and analyzed filtered samples for dissolved P (Murphy and Riley, 1962), and 
$\mathrm{NH}_{4}-\mathrm{N}$ and $\mathrm{NO}_{3}-\mathrm{N}$ using QuickChem methods 12-107-06-2-A (ammonium) and 12-107-04-1-B (nitrate) on a Lachat automated $\mathrm{N}$ analyzer (Lachat, 1996). To measure total $\mathrm{N}$ and $\mathrm{P}$, we digested unfiltered samples in an autoclave with potassium persulfate, with digested samples analyzed for $\mathrm{N}$ and $\mathrm{P}$ by the same methods as the filtered samples (Langner and Hendrix, 1982). We refer to the difference between total and dissolved nutrient forms as particulate $\mathrm{N}$ or $\mathrm{P}$.

We collected soil samples from each pasture basin from $0-2.5$ and $0-15.0 \mathrm{~cm}$ to assess the historical $\mathrm{P}$ accumulation in soils and the degree of $\mathrm{P}$ stratification (i.e., greater $\mathrm{P}$ in the $0-2.5 \mathrm{~cm}$ layer than the $0-15.0 \mathrm{~cm}$ layer due to historical surface manure applications and minimal soil mixing due to lack of tillage). Soil samples were analyzed at the University of Wisconsin Soil and Plant Analysis Lab for Bray-1 P extractable soil P (Bray and Kurtz, 1945) and organic matter (OM) by loss-on-ignition. These data were used as inputs for the APLE model as described below.

\subsection{Determination of event and annual $N$ and $P$ loads}

To determine event sediment, $\mathrm{N}$, and $\mathrm{P}$ loads from each pasture basin, we multiplied the concentration of sediment and measured $\mathrm{N}$ and $\mathrm{P}$ forms ( $\mathrm{mg} \mathrm{L}^{-1}$ ) in runoff samples by the runoff amount from each basin $\left(\mathrm{L} \mathrm{ha}^{-1}\right)$ to determine a load $\left(\mathrm{kg} \mathrm{ha}^{-1}\right)$. Analysis of runoff and nutrient loss data did not reveal any consistent trends in differences between the eight basins. Given this and that all pasture basins had similar management, we treated the basins as replicates and averaged loads across all eight for a single load per event. For annual sediment or nutrient loads, we summed all event loads for two 365-d periods, which were from August 1 to July 31 for both 2010-2011 and 2011-2012.

\subsection{Testing APLE for runoff $P$ loss from pastures}

\subsubsection{APLE description}

APLE is a fairly simple, user-friendly, Microsoft Excel spreadsheet model that runs on an annual time-step and estimates field-scale, sediment bound and dissolved $\mathrm{P}$ loss $\left(\mathrm{kg} \mathrm{ha}^{-1}\right)$ in surface runoff for agricultural field. APLE is intended to have the simplicity of P-indexes, but to quantify $\mathrm{P}$ loss through more process-based equations rather than estimate a risk of $\mathrm{P}$ loss. It has been tested for its ability to reliably predict $\mathrm{P}$ loss in runoff for systems with machine-applied manure and for soil P cycling using data from a wide variety of agricultural fields and regions (Vadas et al., 2007, 2012). APLE is available to download at (http://ars.usda.gov/Services/docs.htm?docid=21763), along with theoretical documentation and a user's manual that describe the model in detail. Here, we present a summary of APLE and how we adapted and tested it for $P$ loss in runoff from grazed pastures.

Pertinent APLE user-input data for this project include topsoil properties (Mehlich-3 soil test P, clay, organic matter); surface area of the field; annual precipitation, runoff, and erosion; annual crop P export; number of annual cattle days in the field; and information for manure and fertilizer $P$ application. APLE operates on an annual time-step, and therefore does not consider variations in climate, hydrology, or other variables that occur throughout a year. It also does not consider landscape or management impacts on runoff and erosion, but instead allows user-input precipitation, runoff, and erosion to account for these variations. Thus, APLE does not predict annual runoff or erosion, but instead estimates $\mathrm{P}$ loss and soil P cycling for a given set of runoff, erosion, and $\mathrm{P}$ application (fertilizer, manure, grazing) conditions. Annual erosion and runoff can be estimated with models such as RUSLE2 (http://fargo.nserl.purdue.edu/rusle2_dataweb/RUSLE2_Index.htm).
APLE estimates annual sediment P loss $\left(\mathrm{kg} \mathrm{ha}^{-1}\right)$ in runoff as:

Sediment $\mathrm{P}$ loss $=($ eroded sediment $)($ soil total $\mathrm{P})(\mathrm{P}$ enrichment ratio $)\left(10^{-6}\right)$

where eroded sediment $\left(\mathrm{kg} \mathrm{ha}^{-1}\right)$ is annual soil erosion; soil total $\mathrm{P}$ $\left(\mathrm{mg} \mathrm{kg}^{-1}\right)$ is estimated using soil Mehlich-3 P, clay, and OM; and $\mathrm{P}$ enrichment ratio is a unitless ratio of total $\mathrm{P}$ in eroded sediment to that in the source soil, and is estimated from annual soil erosion. In this study, we used measured soil Bray-1 P and OM data and assumed that Mehlich-3 was equivalent to Bray-1 (Vadas et al., 2012). APLE estimates dissolved inorganic P loss in runoff $\left(\mathrm{kg} \mathrm{ha}^{-1}\right)$ from soil as:

Dissolved soil runoff $\mathrm{P}=($ soil labile $\mathrm{P})(0.005)$ (annual runoff) $\left(10^{-6}\right)$

where soil labile $\mathrm{P}\left(\mathrm{mg} \mathrm{kg}^{-1}\right)$ is estimated as one half of soil Mehlich-3 $\mathrm{P}$ and annual runoff is in $\mathrm{cm}$.

In APLE, manure is applied in either a solid or liquid form, and fertilizer in a solid form. If tillage occurs, APLE incorporates any applied manure or fertilizer according to user-specified depths of incorporation and percentages of $\mathrm{P}$ applied that are incorporated. APLE estimates annual dissolved $P$ loss directly from any manure or fertilizer remaining on the soil surface. For applied manure, APLE assumes a portion of the manure total $P$ is in a water-extractable $P$ (WEP) form. APLE estimates dissolved manure P loss in runoff from this manure WEP on the soil surface. The portion of manure $P$ that is not in a WEP form (non-WEP) at application can mineralize during the year and add to manure WEP on the soil surface. APLE estimates annual manure or fertilizer dissolved $P$ loss in runoff $\left(\mathrm{kg} \mathrm{ha}^{-1}\right)$ as:

Manure runoff $\mathrm{P}=($ manure $\mathrm{WEP})($ annual runoff/precipitation) (P distr. factor)

Fertilizer runoff $\mathrm{P}=($ fertilizer $\mathrm{P})$ (annual runoff/precipitation) $(\mathrm{P}$ distr. factor)

where manure WEP and fertilizer P are in $\mathrm{kg} \mathrm{ha}^{-1}$ and precipitation and runoff are in $\mathrm{cm}$. The $\mathrm{P}$ distribution factor is an empirical factor between 0.0 and 1.0 that distributes released $P$ between runoff and infiltration, and is calculated as:

Manure: $P$ distribution factor $=($ annual runoff $)$ precipitation $)^{0.225}$

Fertilizer: $P$ distribution factor $=0.034 \exp ((3.4)$ (annual runoff/ precipitation))

The precipitation $(\mathrm{cm})$ represents total rain, snow, and irrigation for an entire 12-month period.

\subsubsection{APLE testing for pastures}

The processes described above for P loss in runoff from soil, manure, and fertilizer have been well tested (Vadas et al., 2009; Good et al., 2012). For this project, we adapted and tested APLE so it would simulate $P$ loss in runoff from dung applied by grazing cattle. In APLE, a user specifies how many dairy or beef cattle graze the field during the year. This adds dung and $P$ to the field and increases the amount of dissolved P loss in runoff. APLE assumes daily dung production and dung total $P$ content for dairy and beef cattle as listed in Table 1 (Nennich et al., 2005). Dung WEP at deposition is set at $55 \%$ of total $\mathrm{P}$, and $75 \%$ of dung WEP is available the same year for P loss in runoff and $25 \%$ is available the following year. APLE also assumes that $20 \%$ of dung non-WEP on the soil surface mineralizes into WEP the same year. 
Table 1

Assumptions used in the APLE model for daily dry mass dung production and dung total $\mathrm{P}$ content for grazing dairy and beef cattle.

\begin{tabular}{lll}
\hline Animal type & $\begin{array}{l}\text { Daily dung production } \\
\mathrm{kg}\end{array}$ & $\begin{array}{l}\text { Dung total P content } \\
\mathrm{kg} \mathrm{kg}^{-1}\end{array}$ \\
\hline Lactating dairy cow & 8.9 & 0.0088 \\
Dairy heifer & 3.7 & 0.0054 \\
Dairy dry cow & 4.9 & 0.0061 \\
Dairy calf & 1.4 & 0.0054 \\
Beef cow & 6.6 & 0.0067 \\
Beef calf & 2.7 & 0.0092 \\
\hline
\end{tabular}

APLE uses Eqs. (3) and (5) to calculate annual dissolved P loss in runoff from grazing dung. In addition, APLE also reduces the amount of dung dissolved $P$ loss in runoff by a factor that accounts for the fact that dung does not evenly cover the entire soil surface, as would be the case for machine applied manure, and not all of the annual precipitation interacts with it to contribute to runoff $P$. In calculating the annual reduction factor for grazing dung, APLE first assumes that each $250 \mathrm{~g}$ of dung (dry weight) covers an area of $659 \mathrm{~cm}^{2}$ (James et al., 2007) and calculates what percentage of the field area is covered by the annual mass of dung deposited. APLE then calculates the dung reduction factor as:

Reduction factor $=1.2 x(250 x \%$ annual cover $) /((250 x \%$ annual cover) + 73.1)

where \% annual cover is expressed as a decimal. Eq. (7) is a non-linear equation that returns a reduction factor greater than the portion of the pasture area covered by dung. We found that during APLE adaptation for pasture $\mathrm{P}$ runoff, a non-linear equation gave better predictions of dissolved $\mathrm{P}$ loss in runoff than a linear equation that reduced runoff $\mathrm{P}$ in direct proportion to the pasture area covered by dung. Eq. (7) is taken from the daily time-step, manure P runoff model of Vadas et al. (2007), where it is used to determine what portion of manure WEP is leached by rain from manure on the soil surface during a storm. Thus, the important new parts of APLE to test were the assumptions for cattle dung production rate and P content (Table 1) and Eq. (7) to reduce dung $P$ loss in runoff according to the amount of pasture area covered.

To test APLE for grazing cattle, we used data from 20 published studies in the literature that monitored field-scale P loss in runoff from grazed pastures (Table 2), as well as data from our pasture runoff monitoring. All literature studies were conducted for at least
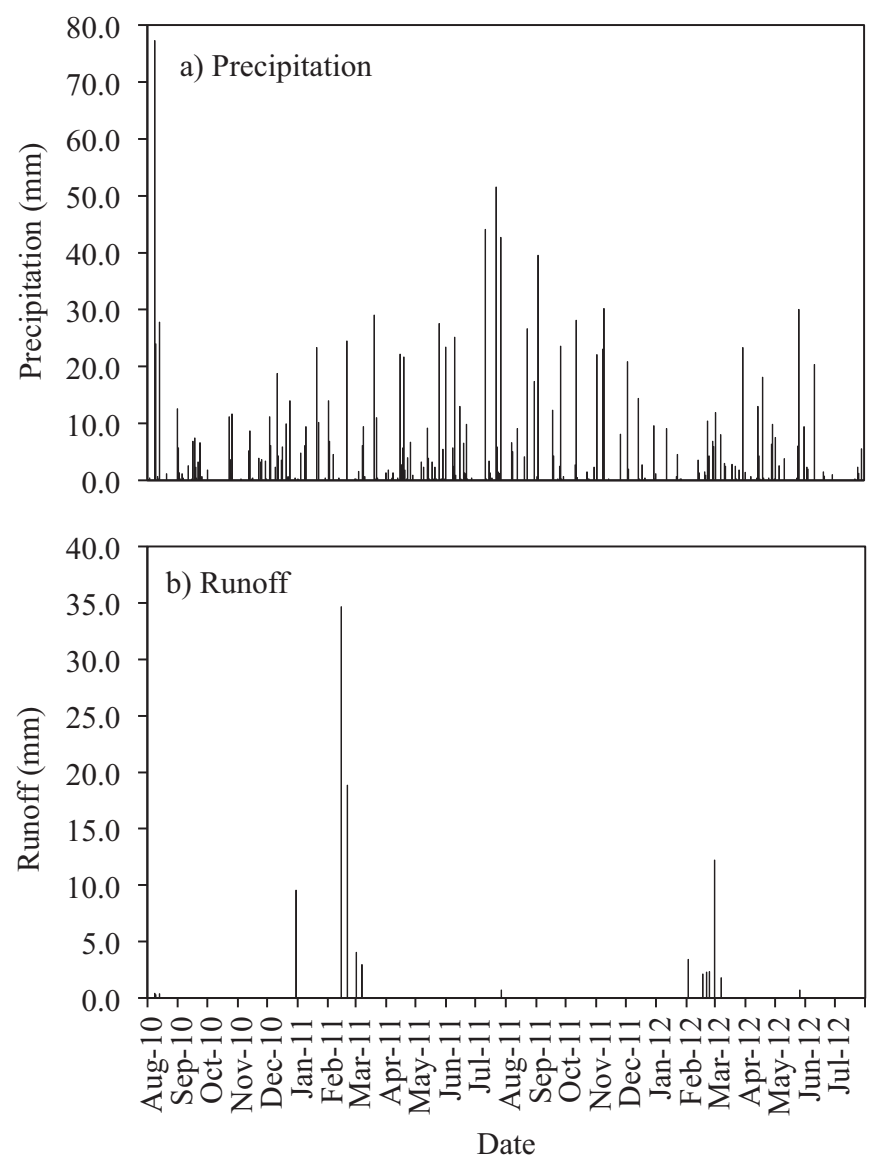

Fig. 2. Precipitation and runoff depths from the eight pasture basins from August 2010 to July 2012.

6 months, and most for multiple years. The studies all reported the input information needed for APLE, including size of field; annual stocking rate; soil $\mathrm{P}$ concentration; fertilizer applications; soil OM and clay content; and annual rain, runoff, and sediment loss. We entered all required input information into APLE, predicted annual $\mathrm{P}$ loss in runoff, and then compared measured and predicted $\mathrm{P}$ loss (both total $\mathrm{P}$ and dissolved $\mathrm{P}$ ) by linear regression to assess how reliably APLE simulated annual P loss from grazed pastures.

Table 2

Details of 20 studies used to validate APLE for P loss in runoff from cattle-grazed pastures.

\begin{tabular}{|c|c|c|c|c|c|}
\hline Reference & Location & $\begin{array}{l}\text { Duration } \\
\text { months }\end{array}$ & $\begin{array}{l}\text { Field area } \\
\text { ha }\end{array}$ & Cattle type & P forms measured \\
\hline (Capece et al., 2007) & Florida, USA & 72 & $20.2-32.4$ & Beef & DRP \\
\hline (Cournane et al., 2011) & New Zealand & 25 & 1.3 & Beef & TP, DRP \\
\hline (Edwards et al., 1996) & Arkansas, USA & 24 & 1.2 & Beef & DRP \\
\hline (Fleming and Cox, 1998) & Australia & 12 & 2.4 & Dairy & DRP \\
\hline (Harmel et al., 2009) & Texas, USA & 84 & 1.2 & Beef & TP, DRP \\
\hline$($ Holz, 2010) & Tasmania & 36 & 12.1 & Dairy & TP, DRP \\
\hline (Kurz et al., 2006) & Ireland & 16 & $0.5-1.5$ & Beef & DRP \\
\hline (Lambert et al., 1985) & New Zealand & 36 & $0.1-1.5$ & Sheep & $\mathrm{TP}$ \\
\hline (Mapfumo et al., 2002) & Canada & 36 & 2.2 & Beef & DRP \\
\hline (McDowell et al., 2003) & New Zealand & 6 & 3.0 & Dairy & TP, DRP \\
\hline (Melland et al., 2008) & Australia & 30 & 0.5 & Sheep & $\mathrm{TP}$ \\
\hline (Menzel et al., 1978) & Oklahoma, USA & 120 & 11.0 & Beef & TP, DRP \\
\hline (Olness et al., 1975) & Oklahoma, USA & 12 & $9.6-11.0$ & Beef & TP, DRP \\
\hline (O'reagain et al., 2005) & Australia & 12 & 1.0 & Beef & $\mathrm{TP}$ \\
\hline (Owens and Shipitalo, 2006) & Ohio, USA & 120 & 17.2 & Beef & DRP \\
\hline (Owens et al., 1983a) & Ohio, USA & 72 & 28.2 & Beef & $\mathrm{TP}$ \\
\hline (Schepers and Francis, 1982) & Nebraska, USA & 36 & 32.5 & Beef & TP, DRP \\
\hline (Smith, 1987) & New Zealand & 20 & 16 & Sheep & TP, DRP \\
\hline (Smith and Monaghan, 2003) & New Zealand & 36 & 0.09 & Beef, dairy & DRP \\
\hline (Vankeuren et al., 1979) & Ohio, USA & 24 & 17.2 & Beef & $\mathrm{TP}$ \\
\hline
\end{tabular}




\section{Results and discussion}

\subsection{Runoff monitoring at Pioneer Farm}

Fig. 2 shows precipitation and runoff depths for our pasture-monitoring period between August 2010 and July 2012. There were 16 runoff events during this period that generated 102 runoff samples (Table 3), meaning that not all eight basins had runoff for all events. Only five events and 30 samples were caused by rain outside of winter periods (December 1-March 31), with all other events and samples due to snowmelt or rain-on-snow. Although runoff is clearly weather dependent, these data suggest that most runoff from pastures in Wisconsin on similar soil types may occur in winter and early spring from snowmelt, with less runoff from rain outside of this period.

Tables 3 and 4 show results for sediment and nutrient loss in runoff for the grazed pastures. In the 102 runoff samples, sediment concentrations were consistently very low, averaging only $0.20 \mathrm{~g} \mathrm{~L}^{-1}$, with a maximum of only $1.3 \mathrm{~g} \mathrm{~L}^{-1}$. Sediment runoff concentrations did not vary appreciably through time. However, average sediment runoff concentrations were greater during the non-winter period than the winter period, showing that rainfall-induced runoff was more erosive than snowmelt runoff. Overall though, data clearly show that well-established pasture vegetation can effectively eliminate soil erosion (Owens et al., 1983b; Butler et al., 2006; Bartley et al., 2010).

Runoff dissolved $\mathrm{NO}_{3}-\mathrm{N}$ and $\mathrm{NH}_{4}-\mathrm{N}$ concentrations were generally low throughout the study and did not vary substantially through time (Tables 3 and 4). Particulate runoff $\mathrm{N}$ concentrations (total $\mathrm{N}$ less $\mathrm{NO}_{3}-\mathrm{N}$ and $\mathrm{NH}_{4}-\mathrm{N}$ ) were fairly well, non-linearly related to runoff sediment concentrations (particulate $\mathrm{N}=1.03 x \ln$ runoff sediment $\left.-1.85 ; r^{2}=0.46\right)$. Runoff particulate
$P$ concentrations were similarly related to runoff sediment (particulate $\mathrm{P}=0.24 x$ ln runoff sediment $-0.69 ; r^{2}=0.43$ ). Strong relationships between sediment loss and particulate nutrient loss are common (Vadas et al., 2004; Kleinman et al., 2011). Generally, runoff $\mathrm{P}$ concentrations did not vary drastically through time. About $80 \%$ of runoff samples had dissolved $P$ between 0.5 and $2.5 \mathrm{mg} \mathrm{L}^{-1}$, and total $\mathrm{P}$ between 1.0 and $3.0 \mathrm{mg} \mathrm{L}^{-1}$. Dissolved $P$ averaged $80 \%$ of total $P$ in the winter-period, snowmelt samples and $60 \%$ in the non-winter, rain-runoff samples. The magnitude of these $P$ concentrations is consistent with runoff observations from the similar study of Owens and Shipitalo (2006), where well established pastures were grazed by beef cattle over several years under similar climate conditions in Ohio, USA.

The chemical forms of runoff nutrient concentrations did vary as a function of season. Average particulate $\mathrm{N}$ and $\mathrm{P}$ concentrations were greater during the non-winter period (3.83 vs $3.25 \mathrm{mg} \mathrm{L}^{-1}$ for $\mathrm{N}$, and $0.63 \mathrm{vs} 0.43 \mathrm{mg} \mathrm{L}^{-1}$ for $\mathrm{P}$ ), which follows the runoff sediment data. These results were statistically significant $(p=0.05)$ for $\mathrm{P}$, but not for $\mathrm{N}$. Conversely, dissolved $\mathrm{N}$ and $\mathrm{P}$ concentrations were both significantly $(p=0.05)$ greater during the winter period. This is despite the relatively long time between fresh dung deposition during grazing and winter runoff events, which is somewhat contrary to research that shows nutrient concentrations in runoff are often greatest shortly after grazing events (Dougherty et al., 2008). Greater winter dissolved nutrient concentrations, especially for $\mathrm{P}$, may have been caused by freezing of vegetation and associated greater release of nutrients upon thawing, which may not occur for dung (Miller et al., 1994; Bechmann et al., 2005). Overall, the increase in particulate concentrations during non-winter periods was less than the increase in dissolved concentrations during the winter period, so that overall total nutrient runoff concentrations were greater

Table 3

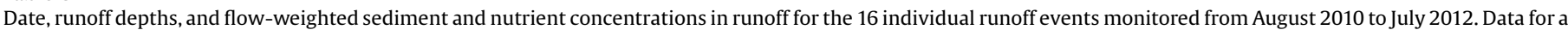
given event are averages of the eight cattle pasture basins.

\begin{tabular}{|c|c|c|c|c|c|c|c|}
\hline Date & Runoff & Sediment & Dissolved P & Total P & $\mathrm{NH}_{4}-\mathrm{N}$ & $\mathrm{NO}_{3}-\mathrm{N}$ & Total N \\
\hline & $\mathrm{cm}$ & $\mathrm{mg} \mathrm{L}^{-1}$ & & & & & \\
\hline $8 / 8 / 10$ & 0.04 & 108.81 & 0.51 & 0.84 & 0.54 & 0.40 & 4.37 \\
\hline $8 / 9 / 10$ & 0.03 & 225.77 & 0.71 & 1.26 & 0.59 & 0.61 & 4.82 \\
\hline $8 / 13 / 10$ & 0.04 & 156.35 & 1.02 & 1.53 & 0.80 & 0.39 & 4.88 \\
\hline $12 / 30 / 10$ & 0.96 & 74.65 & 1.46 & 1.60 & 0.75 & 0.73 & 2.93 \\
\hline $2 / 14 / 11$ & 3.47 & 80.38 & 1.99 & 2.27 & 5.07 & 0.75 & 9.10 \\
\hline $2 / 20 / 11$ & 1.88 & 69.68 & 1.26 & 1.48 & 2.47 & 0.72 & 5.33 \\
\hline $3 / 1 / 11$ & 0.41 & 123.92 & 1.62 & 2.14 & 3.11 & 0.83 & 3.76 \\
\hline $3 / 7 / 11$ & 0.30 & 295.42 & 3.25 & 4.09 & 3.05 & 1.81 & 9.19 \\
\hline $7 / 27 / 11$ & 0.07 & 567.66 & 1.33 & 2.26 & 0.33 & 1.31 & 5.58 \\
\hline $2 / 2 / 12$ & 0.34 & 167.35 & 2.11 & 2.82 & 1.97 & 1.09 & 6.14 \\
\hline $2 / 17 / 12$ & 0.21 & 72.53 & 1.81 & 2.17 & 1.37 & 0.47 & 4.19 \\
\hline $2 / 21 / 12$ & 0.23 & 112.23 & 1.74 & 2.13 & 1.68 & 0.82 & 5.11 \\
\hline $2 / 24 / 12$ & 0.23 & 377.48 & 1.71 & 2.24 & 1.44 & 0.81 & 6.60 \\
\hline $2 / 29 / 12$ & 1.22 & 239.57 & 1.26 & 1.74 & 1.24 & 0.40 & 5.29 \\
\hline $3 / 7 / 12$ & 0.18 & 269.18 & 2.38 & 2.94 & 1.26 & 0.78 & 6.25 \\
\hline $5 / 26 / 12$ & 0.07 & 388.07 & 2.55 & 3.50 & 3.48 & 0.80 & 12.03 \\
\hline
\end{tabular}

Table 4

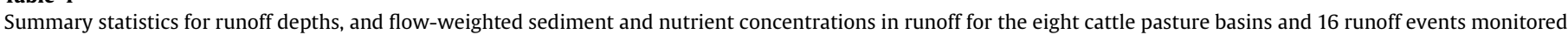
from August 2010 to July 2012. Data are across all samples for all events.

\begin{tabular}{|c|c|c|c|c|c|c|}
\hline Statistic & $\begin{array}{l}\text { Sediment } \\
\mathrm{mg} \mathrm{L}^{-1}\end{array}$ & Dissolved P & Total P & $\mathrm{NH}_{4}-\mathrm{N}$ & $\mathrm{NO}_{3}-\mathrm{N}$ & Total N \\
\hline Average & 200.1 & 1.5 & 2.0 & 1.8 & 0.8 & 5.9 \\
\hline Maximum & 1331.8 & 4.3 & 5.2 & 12.3 & 4.4 & 21.0 \\
\hline Minimum & 13.3 & 0.1 & 0.5 & 0.1 & 0.0 & 2.4 \\
\hline Std. dev. & 206.3 & 0.8 & 0.9 & 2.0 & 0.5 & 3.2 \\
\hline Winter average & 152.7 & 1.7 & 2.2 & 2.3 & 0.8 & 6.1 \\
\hline Non-winter average & 279.9 & 1.0 & 1.5 & 0.7 & 0.7 & 5.2 \\
\hline
\end{tabular}


Table 5

Measured 12-month period precipitation, runoff, and sediment and P loss in runoff from cattle pastures from August 2010 to July 2012.

\begin{tabular}{llllll}
\hline Time period & $\begin{array}{l}\text { Precipitation } \\
\mathrm{cm}\end{array}$ & $\begin{array}{l}\text { Runoff } \\
\mathrm{cm}\end{array}$ & $\begin{array}{l}\text { Sediment } \\
\mathrm{kg} \mathrm{ha}^{-1}\end{array}$ & $\begin{array}{l}\text { Dissolved P } \\
\mathrm{kg} \mathrm{ha}^{-1}\end{array}$ & $\begin{array}{l}\text { Total P } \\
\mathrm{kg} \mathrm{ha}^{-1}\end{array}$ \\
\hline $2010-2011$ & 86.0 & 6.7 & 66.6 & 1.2 & 1.4 \\
$2011-2012$ & 58.3 & 2.0 & 62.6 & 0.4 & 0.6 \\
\hline
\end{tabular}

during the winter period. These results were statistically significant $(p=0.05)$ for $\mathrm{P}$, but not for $\mathrm{N}$.

We compiled measured runoff volume and sediment and $P$ concentration data from all events to calculate annual runoff, erosion, and $\mathrm{P}$ loss from the cattle pastures (Table 5). Both annual precipitation and runoff were greater in the 2010-2011 period than the 2011-2012 period. Average annual precipitation for this location (1971-2001) is $91.7 \mathrm{~cm}$. Thus for years with about average precipitation (2010-2011), about 5-10\% of annual precipitation may be expected to become runoff from similar grazed cattle pastures. In years with less than average precipitation (2011-2012), less than 5\% of precipitation may become runoff. These results are consistent with data from Owens and Shipitalo (2006) where average annual runoff from grazed pastures ranged from about 2 to $13 \%$ of average annual precipitation. Such information is useful for models like APLE that require annual precipitation and runoff as input. Model users will readily know typical annual precipitation, and annual runoff can be estimated as a percentage of that precipitation for a given soil type and land use. Thus, a model user could be confident in assuming annual runoff from similar pastures may be $5-10 \%$ of annual precipitation.

Annual erosion from the pastures was very low, at less than $70 \mathrm{~kg} \mathrm{ha}^{-1}$, and annual nutrient loss was only $1.5-4.3 \mathrm{~kg}$ total $\mathrm{N}$ ha ${ }^{-1} \mathrm{P}$ and $0.6-1.6 \mathrm{~kg}$ total $\mathrm{Pha}^{-1}$. These $\mathrm{P}$ results are consistent with data in the literature on the magnitude of P loss from grazed pastures. For example, of the 20 pasture runoff studies in Table 2 , about $85 \%$ of the site years had less than $2.0 \mathrm{~kg} \mathrm{ha}^{-1}$ of annual total $\mathrm{P}$ loss and less than $1.5 \mathrm{~kg} \mathrm{ha}^{-1}$ of dissolved P loss. Based on our cattle stocking rates, and assuming that cattle excrete $0.23 \mathrm{~kg} \mathrm{~N}$ day $^{-1}$ and $0.04 \mathrm{~kg} \mathrm{P}$ day $^{-1}$ on a dry weight basis (Nennich et al., 2005), annual nutrient application rates to pastures were about $225 \mathrm{~kg} \mathrm{Nha}^{-1}$ and $39 \mathrm{~kg} \mathrm{Pha}^{-1}$. Thus the rate of nutrient loss in runoff per unit of applied nutrient was about $1.3 \%$ for $\mathrm{N}$ and $2.5 \%$ for $P$. In general, these results show that annual runoff, erosion, and nutrient loss from similar cattle-grazed pastures in Wisconsin are likely low relative to other agricultural land uses (Beaulac and Reckhow, 1982), and may not pose as much of a risk to local water quality. However, management practices that increase runoff, erosion, and nutrient loss, such as significantly greater cattle stocking rates and related erosion, or excessive fertilization, could increase the risk of negative environmental impact. As demonstrated below, the APLE model could be easily used to quantify how much more P would be lost due to greater erosion, stocking rate, or fertilization.

\subsection{Testing of APLE for P loss from cattle pastures}

To assess APLE for grazing cattle, we used data from 20 published studies in the literature that monitored annual $\mathrm{P}$ loss in runoff from grazed pastures (Table 2). The data represented a variety of stock types, field areas, and locations and associated climate. This variety provided a robust test to see if APLE could reliably estimate annual $P$ loss in runoff from pastures. Since we used measured runoff and erosion as model inputs, this assessment assessed the ability of APLE to reliably estimate the impact of $\mathrm{P}$ sources (i.e., soil $\mathrm{P}$ and dung $\mathrm{P}$ ) on $\mathrm{P}$ loss given a set of transport (i.e., runoff and erosion) conditions.
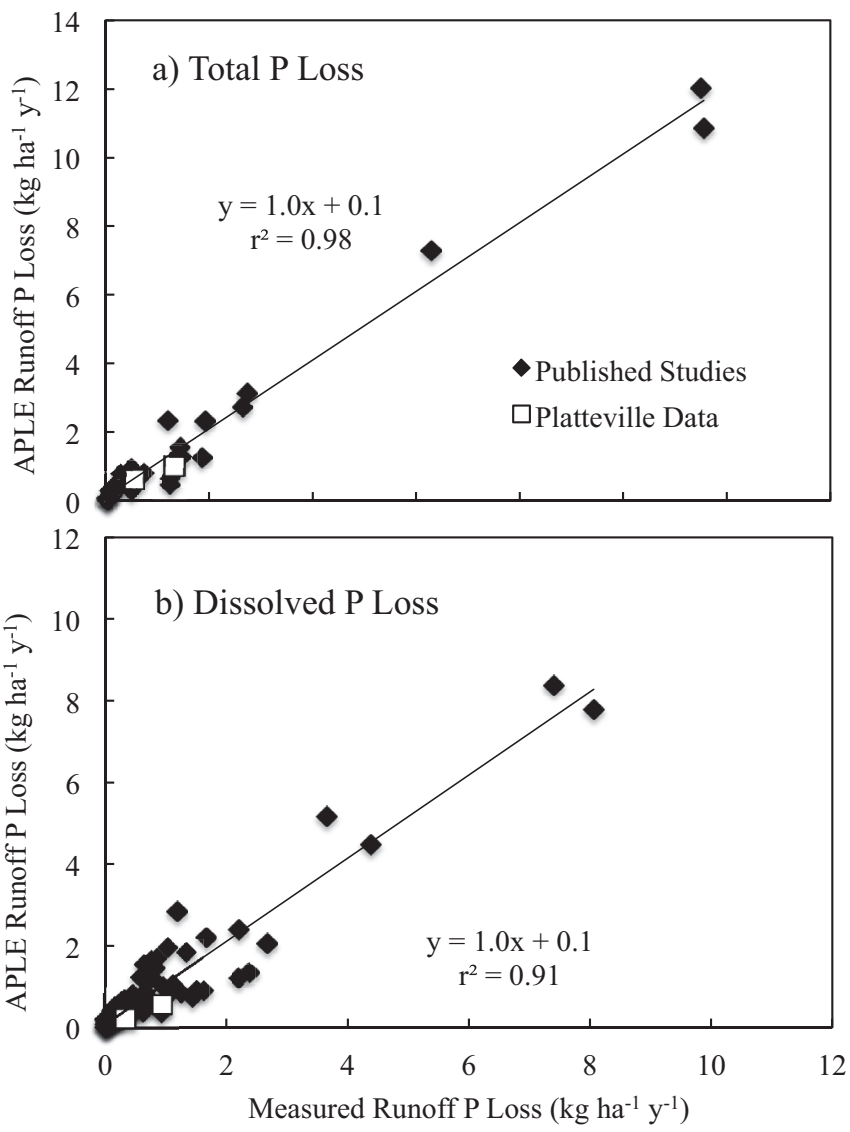

Fig. 3. Measured and APLE-simulated runoff $P$ loss from cattle-grazed pastures. Data are from 19 published studies and from monitoring at the UW Platteville Pioneer Farm, for (a) total P in loss $(n=33)$ and (b) dissolved P loss $(n=82)$.

Fig. 3 shows the relationship between measured and predicted, annual total and dissolved P loss in runoff from cattle pastures. Results show APLE was able to reliably estimate annual $P$ loss in runoff. The slope and intercept of both regression lines relating measured and predicted values were not significantly $(p<0.05)$ different from one or zero, respectively. The model predicted the measured total $P$ data with an efficiency of 0.98 and the dissolved P data with an efficiency of 0.89 (Nash and Sutcliffe, 1970). Nash-Sutcliffe efficiencies can range from $-\infty$ to 1 . An efficiency of 1 corresponds to a perfect match of modeled and observed data. An efficiency of zero indicates that model predictions are as accurate as the mean of observed data, and efficiency less than zero occurs when the observed mean is a better predictor than the model.

The important new parts of APLE to validate for pasture P runoff were the assumptions for dung production and P content (Table 1) and Eq. (7) to reduce dung $P$ loss in runoff according to the amount of field area covered by dung. Runoff $P$ prediction results in Fig. 3 suggest that these two parts of the model provided reliable estimates of pasture $P$ runoff. In fact, without the dung area reduction factor (Eq. (7)), which would ultimately treat grazing dung the same as machine-applied manure, $\mathrm{P}$ loss predictions were about 50\% greater than measured data. This demonstrates the importance of simulating dung deposited during grazing differently from machine-applied manure.

We also conducted a model sensitivity analysis to determine how much assumptions about dung and $\mathrm{P}$ production as well as dung cover influence model predictions compared to runoff volume, which is the model transport variable for manure P loss. To do this, we determined how much both increasing and 
Table 6

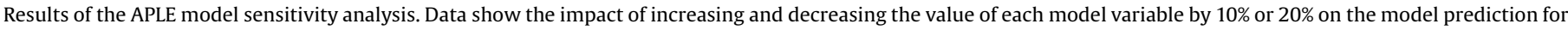
annual dissolved $P$ loss in runoff from cattle dung.

\begin{tabular}{|c|c|c|c|c|}
\hline Model variable & $+10 \%$ & $-10 \%$ & $+20 \%$ & $-20 \%$ \\
\hline Runoff & 12.4 & -12.1 & 25.0 & -23.9 \\
\hline Dung total P excreted & 10.0 & -10.0 & 20.0 & -20.0 \\
\hline Dung WEP content & 6.0 & -6.0 & 12.0 & -12.0 \\
\hline Dung cover & 6.0 & -6.5 & 11.7 & -13.6 \\
\hline Dung reduction factor & 10.0 & -10.0 & 20.0 & -20.0 \\
\hline
\end{tabular}

decreasing each variable by $10 \%$ and $20 \%$ changed model predictions for manure $P$ loss in runoff. Specific model variables changed were runoff amount, the amount of dung total $P$ excreted by grazing cattle, the WEP content of the grazing dung, the amount of area covered by the dung, and the reduction factor in Eq. (7). Sensitivity results are shown in Table 6 . The model was most sensitive to changes in annual runoff, showing this transport factor significantly influences model prediction of dung P loss. The model was linearly sensitive to assumptions for dung total P excretion and the dung $\mathrm{P}$ loss reduction factor, so that each unit change in input had the same unit change in output. These changes were also nearly as much as changes for runoff volume, showing that the new assumptions developed in this project for dung $\mathrm{P}$ excretion and dung reduction factor are important model parameters. Model predictions were least sensitive to changes in dung WEP content and dung area covered, with the influence of these parameters about half of the influence of the previous parameters.

One benefit of the APLE model is that it gives information on the relative contribution of different sources to total $P$ loss in runoff from pastures, including fertilizer, dung, soil, and eroded sediment. The relative importance of each source will of course depend on pasture management. For example, for the studies in Table 2 that monitored total P loss in runoff, APLE estimated that P loss from applied fertilizer ranged from 0 to $37 \%$ of total $P$ loss, with ranges for dung from 3 to $67 \%$, soil from 3 to $56 \%$, and eroded sediment from 13 to $89 \%$. However, on average for the same studies, the relative contribution to total $\mathrm{P}$ loss was about $10 \%$ from fertilizer, $15 \%$ from soil dissolved P, 30\% from dung, and 45\% from soil erosion. In New Zealand, McDowell et al. (2007) used data from a series of controlled experiments and empirical equations to make similar estimates of annual $P$ loss from grazed pastures. They found that of the estimated $\mathrm{P}$ losses, fertilizer comprised $12-13 \%$, soil $\mathrm{P}$ (combination of dissolved and eroded P) comprised 29-45\%, dung P losses comprised 28-38\%, and P from pasture-plants was $15-21 \%$. These New Zealand P source divisions for fertilizer, soil, and dung agree well with estimates from our pasture $P$ runoff research, except that APLE does not consider loss from pasture plants. Such $P$ loss source data are a potentially powerful benefit of APLE and similar models for considering how to better manage P loss. Since P loss sources can vary considerably from site to site, these models become invaluable tools for site-specific P management, especially because it is infeasible to rely on physical monitoring of all sites of interest.

\section{Conclusions}

Our project monitored sediment and nutrient loss in runoff from dairy and beef grazed pastures for typical Wisconsin conditions. Results over two annual monitoring periods show that pasture sediment and nutrient loss were generally low, likely having less negative impact on local water quality than other agricultural land uses. We used these data along with data from 20 studies in the literature, to update the APLE model to estimate annual $\mathrm{P}$ loss in runoff from grazed pastures. Our results demonstrate that APLE is able to reliably estimate P loss from beef and dairy grazed pastures given reliable estimates of annual runoff and erosion. Models like APLE can be used to rapidly and cost-effectively identify which sources (i.e., dung, soil dissolved P, or particulate $\mathrm{P}$ ) dominate $\mathrm{P}$ loss, making them valuable tools for site-specific $P$ loss assessments and mitigation strategies. APLE will also play a critical role in our future research to simulate whole-farm $\mathrm{P}$ loss on dairy farms and identify which land uses represent the greatest risk for $\mathrm{P}$ loss and help target remediation.

\section{Acknowledgement}

Funding for this project was provided in part by the Wisconsin Department of Agriculture's Grazing Lands Conservation Initiative Grant program.

\section{References}

Arnold, J.G., Srinivasan, R., Muttiah, R.S., Williams, J.R., 1998. Large area hydrologic modeling and assessment - part 1: model development. J. Am. Water Resour. Assoc. 34, 73-89.

Bartley, R., Corfield, J.P., Abbott, B.N., Hawdon, A.A., Wilkinson, S.N., Nelson, B., 2010 Impacts of improved grazing land management on sediment yields, part 1: hills lope processes. J. Hydrol. 389, 237-248.

Beaulac, M.N., Reckhow, K.H., 1982. An examination of land-use - nutrient export relationships. Water Resour. Bull. 18, 1013-1024.

Bechmann, M.E., Kleinman, P.J.A., Sharpley, A.N., Saporito, L.S., 2005. Freeze-thaw effects on phosphorus loss in runoff from manured and catch-cropped soils. J. Environ. Qual. 34, 2301-2309.

Bennett, E.M., Carpenter, S.R., Caraco, N.F. 2001. Human impact on erodable phosphorus and eutrophication: a global perspective. Bioscience 51, 227-234.

Bray, R.H., Kurtz, L.T., 1945. Determination of total: organic and available phosphorus in soils. Soil Sci. 59, 39-46.

Butler, D.M., Franklin, D.H., Ranells, N.N., Poore, M.H., Green, J.T., 2006. Ground cover impacts on sediment and phosphorus export from manured riparian pasture. J. Environ. Qual. 35, 2178-2185.

Capece, J.C., Campbell, K.L., Bohlen, P.J., Graetz, D.A., Portier, K.M., 2007. Soil phosphorus, cattle stocking rates, and water quality in subtropical pastures in Florida, USA. Rangel. Ecol. Manage. 60, 19-30.

Chichester, F.W., Vankeuren, R.W., Mcguinness, J.L., 1979. Hydrology and chemicalquality of flow from small pastured watersheds. II. Chemical-quality. J. Environ. Qual. 8, 167-171.

Cournane, F.C., McDowell, R., Littlejohn, R., Condron, L., 2011. Effects of cattle: sheep and deer grazing on soil physical quality and losses of phosphorus and suspended sediment losses in surface runoff. Agric. Ecosys. Environ. 140, 264-272.

Dougherty, W.J., Milham, P.J., Havilah, E.J., Lawrie, R.A., 2008. Phosphorus fertilizer and grazing management effects on phosphorus in runoff from dairy pastures. J. Environ. Qual. 37, 417-428.

Edwards, D.R., Daniel, T.C., Murdoch, J.E., Moore, P.A., 1996. Quality of runoff from four northwest Arkansas pasture fields treated with organic and inorganic. Trans. ASAE 39, 1689-1696.

Edwards, D.R., Hutchens, T.K., Rhodes, R.W., Larson, B.T., Dunn, L., 2000. Quality of runoff from plots with simulated grazing. J. Am. Water Resour. Assoc. 36 1063-1073.

Fleming, N.K., Cox, J.W., 1998. Chemical losses off dairy catchments located on a texture-contrast soil: carbon, phosphorus, sulfur, and other chemicals. Aust. J. Soil Res. 36, 979-995.

Gassman, P.W., Williams, J.R., Wang, X., Saleh, A., Osei, E., Hauck, L.M., Izaurralde, R.C., Flowers, J.D., 2010. The agricultural policy/environmental extender (apex) model: an emerging tool for landscape and watershed environmental analyses. Trans. ASABE 53, 711-740.

Good, L.W., Vadas, P., Panuska, J.C., Bonilla, C.A., Jokela, W.E., 2012. Testing the Wisconsin phosphorus index with year-round, field-scale runoff monitoring. J. Environ. Qual. 41, 1730-1740.

Haan, M.M., Russell, J.R., Powers, W.J., Kovar, J.L., Benning, J.L., 2006. Grazing management effects on sediment and phosphorus in surface runoff. Rangel. Ecol. Manage. 59, 607-615. 
Halliwell, D., Coventry, J., Nash, D., 2000. Inorganic monophosphate determination in overland flow from irrigated grazing systems. Int. J. Environ. Anal. Chem. 76, 77-87.

Harmel, R.D., King, K.W., 2005. Uncertainty in measured sediment and nutrient flux in runoff from small agricultural watersheds. Trans. ASAE 48, 1713-1721.

Harmel, R.D., Smith, D.R., Haney, R.L., Dozier, M., 2009. Nitrogen and phosphorus runoff from cropland and pasture fields fertilized with poultry litter. J. Soil Water Conserv. 64, 400-412.

Holz, G.K., 2010. Sources and processes of contaminant loss from an intensively grazed catchment inferred from patterns in discharge and concentration of thirteen analytes using high intensity sampling. J. Hydrol. 383, 194-208.

James, E., Kleinman, P., Veith, T., Stedman, R., Sharpley, A., 2007. Phosphorus contributions from pastured dairy cattle to streams of the Cannonsville Watershed, New York. J. Soil Water Conserv. 62, 40-47.

Kleinman, P.J.A., Sharpley, A.N., Buda, A.R., McDowell, R.W., Allen, A.L., 2011. Soil controls of phosphorus in runoff: management barriers and opportunities. Can. J. Soil Sci. 91, 329-338.

Kurz, I., O'Reilly, C.D., Tunney, H., 2006. Impact of cattle on soil physical properties and nutrient concentrations in overland flow from pasture in Ireland. Agric. Ecosys. Environ. 113, 378-390.

Lachat, 1996. Determination of total Kjeldahl nitrogen in soils and plants by flow injection analysis. QuickChem Method 13-107-06-2-D. Lachat Instruments, Mequon, WI.

Lambert, M.G., Devantier, B.P., Nes, P., Penny, P.E., 1985. Losses of nitrogen phosphorus and sediment in runoff from hill country under different fertilize and grazing management regimes. New Zeal. J. Agric. Res. 28, 371-379.

Langner, C.L., Hendrix, P.F., 1982. Evaluation of a persulfate digestion method for particulate nitrogen and phosphorus. Water Res. 16, 1451-1454.

Mapfumo, E., Willms, W.D., Chanasyk, D.S., 2002. Water quality of surface runoff from grazed fescue grassland watersheds in Alberta. Water Qual. Res. J. Can. 37, 543-562.

McDowell, R.W., Drewry, J.J., Muirhead, R.W., Paton, R.J., 2003. Cattle treading and phosphorus and sediment loss in overland flow from grazed cropland. Aust. J. Soil Res. 41, 1521-1532.

McDowell, R.W., Nash, D., 2012. A review of the cost-effectiveness and suitability of mitigation strategies to prevent phosphorus loss from dairy farms in New Zealand and Australia. J. Environ. Qual. 41, 680-693.

McDowell, R.W., Nash, D.M., Robertson, F., 2007. Sources of phosphorus lost from a grazed pasture receiving simulated rainfall. J. Environ. Qual. 36, 1281-1288.

Melland, A.R., Mc Caskill, M.R., White, R.E., Chapman, D.F., 2008. Loss of phosphorus and nitrogen in runoff and subsurface drainage from high and low input pastures grazed by sheep in southern Australia. Aust. J. Soil Res. 46, 161-172.

Menzel, R.G., Rhoades, E.D., Olness, A.E., Smith, S.J., 1978. Variability of annual nutrient and sediment discharges in runoff from Oklahoma cropland and rangeland. J. Environ. Qual. 7, 401-406.

Miller, M.H., Beauchamp, E.G., Lauzon, J.D., 1994. Leaching of nitrogen and phosphorus from the biomass of 3 cover crop species. J. Environ. Qual. 23, 267-272.

Murphy, J., Riley, J.P., 1962. A modified single solution method for determination of phosphate in natural waters. Anal. Chim. Acta 27, 31-36.

Nash, D., Hannah, M., Halliwell, D., Murdoch, C., 2000. Factors affecting phosphorus export from a pasture-based grazing system. J. Environ. Qual. 29, 1160-1166.
Nash, J.E., Sutcliffe, J.V., 1970. River flow forecasting through conceptual models part I - a discussion of principles. J. Hydrol. 10, 282-290.

Nennich, T.D., Harrison, J.H., VanWieringen, L.M., Meyer, D., Heinrichs, A.J., Weiss, W.P., St-Pierre, N.R., Kincaid, R.L., Davidson, D.L., Block, E., 2005. Prediction of manure and nutrient excretion from dairy cattle. J. Dairy Sci. 88, 3721-3733.

O'reagain, P.J., Brodie, J., Fraser, G., Bushell, J.J., Holloway, C.H., Faithful, J.W., Haynes, D., 2005. Nutrient loss and water quality under extensive grazing in the upper Burdekin river catchment, North Queensland. Mar. Pollut. Bull. 51, 37-50.

Olness, A., Smith, S.J., Rhoades, E.D., Menzel, R.G., 1975. Nutrient and sediment discharge from agricultural watersheds in Oklahoma. J. Environ. Qual. 4, 331-336.

Owens, L.B., Edwards, W.M., Vankeuren, R.W., 1983a. Surface runoff water-quality comparisons between unimproved pasture and woodland. J. Environ. Qual. 12, 518-522.

Owens, L.B., Shipitalo, M.J., 2006. Surface and subsurface phosphorus losses from fertilized pasture systems in Ohio. J. Environ. Qual. 35, 1101-1109.

Owens, L.B., Vankeuren, R.W., Edwards, W.M., 1983b. Hydrology and soil loss from a high-fertility, rotational pasture program. J. Environ. Qual. 12, 341-346.

Parris, K., 2011. Impact of agriculture on water pollution in OECD countries: recent trends and future prospects. Int. J. Water Resour. D 27, 33-52.

Radcliffe, D.E., Freer, J., Schoumans, O., 2009. Diffuse phosphorus models in the United States and Europe: their usages, scales, and uncertainties. J. Environ. Qual. 38, 1956-1967.

Rotz, C.A., Soder, K.J., Skinner, R.H., Dell, C.J., Kleinman, P.J.A., Schmidt, J.P., Bryant, R.B., 2009. Grazing can reduce the environmental impacts of dairy production systems. Plant Manage. Network (September).

Schepers, J.S., Francis, D.D., 1982. Chemical water-quality of runoff from grazing land in Nebraska: I. Influence of grazing livestock. J. Environ. Qual. 11, 351-354.

Sedorovich, D.M., Rotz, C.A., Vadas, P.A., Harmel, R.D., 2007. Simulating management effects on phosphorus loss from farming systems. Trans. ASABE 50, 1443-1453.

Smith, C., Monaghan, R.M., 2003. Nitrogen and phosphorus losses in overland flow from a cattlegrazed pasture in Southland. New Zeal. J. Agric. Res, 46, 225-237.

Smith, C.M., 1987. Sediment, phosphorus, and nitrogen in channelized surface run-off from a New-Zealand pastoral catchment. New Zeal. J. Mar. Fresh. 21, 627-639.

Vadas, P.A., Aarons, S.R., Butler, D.M., Dougherty, W.J., 2011. A new model for dung decomposition and phosphorus transformations and loss in runoff. Soil Res. 49, 367-375.

Vadas, P.A., Gburek, W.J., Sharpley, A.N., Kleinman, P.J.A., Moore, P.A., Cabrera, M.L., Harmel, R.D., 2007. A model for phosphorus transformation and runoff loss for surface-applied manures. J. Environ. Qual. 36, 324-332.

Vadas, P.A., Good, L.W., Moore, P.A., Widman, N., 2009. Estimating phosphorus loss in runoff from manure and fertilizer for a phosphorus loss quantification tool. J. Environ. Qual. 38, 1645-1653.

Vadas, P.A., Joern, B.C., Moore, P.A., 2012. Simulating soil phosphorus dynamics for a phosphorus loss quantification tool. J. Environ. Qual. 41, 1750-1757.

Vadas, P.A., Meisinger, J.J., Sikora, L.J., McMurtry, J.P., Sefton, A.E., 2004. Effect of poultry diet on phosphorus in runoff from soils amended with poultry manure and compost. J. Environ. Qual. 33, 1845-1854.

Vankeuren, R.W., Mcguinness, J.L., Chichester, F.W., 1979. Hydrology and chemicalquality of flow from small pastured watersheds. I. Hydrology. J. Environ. Qual. 8, 162-166. 